\title{
Turkey's Norm Diffusion Policies toward the Middle East: Turkey's Role of Norm Entrepreneur and Norm Transmitter
}

\author{
Kohei Imai ${ }^{*}$
}

\begin{abstract}
This paper examines how Turkey has established and transformed particular norms as norm entrepreneur and norm transmitter toward the Middle East from constructivism perspectives. At first part, this study reviews previous studies about norm and norm spread, especially contributions of Florini, Finnemore and Sikkink, and Acharya. In second part, this paper presents framework of Turkey's norm entrepreneur and norm transmitter roles, and applies it to specific examples. As the examples of norm entrepreneur, Ankara Forum and Turkish model are taken. On the other hand, Turkey's activities in Democratic Assistance Dialogue and in OIC were examples of norm transmitter.
\end{abstract}

\section{Keywords}

Norm Diffusion, Norm Entrepreneur, Norm Transmitter, JDP, Conservative Democracy

\footnotetext{
* Kohei Imai, PhD, is a research assistant in the Department of Law, Chuo University, Tokyo, Japan.
} 


\section{Introduction}

After the Iraq war happened on March 2003, Turkish foreign policy toward the Middle East has clearly changed and started to positive engagement to regional problems. On 29 January 2004, Turkish Prime Minister Recep Tayyip Erdoğan mentioned Turkey's new role in the Middle East.

Turkey will achieve this not merely through its economic and military power, but its ability to make contributions to the universally accepted values and facilitate their dissemination and interaction among various part of the world. In this sense, Turkey in its region and especially in the Middle East will be a guide in overcoming instability, a driving force for economic development, and a reliable partner in ensuring security. Turkey's democratization is a self-imposed process. In other words, it is the result of the free choice of the predominantly Muslim Turkish society. I do not claim, of course, that Turkey's experience does have a substance which can serve as a source of inspiration for other Muslim societies, other Muslim peoples. However, the Turkish experience does have a substance which can serve as a source of inspiration for other Muslim societies, other Muslim peoples. ${ }^{1}$

According to this statement, Turkey wants to be one of the leading actors in the Middle East. But what kind of contribution can Turkey do in the Middle East? This paper focuses on the Turkey's norm diffusion policies as norm entrepreneur and norm transmitter.

For a long time, to settle democracy in the Middle East has been one of the most controversial topics for the Middle Eastern

\footnotetext{
${ }^{1}$ Recep T. Erdoğan, "Conservative Democracy and the Globalization of Freedom", The Emergence of A New Turkey: Democracy and the AK Parti, ed. Hakan Yavuz, Salt Lake City, University of Utah Press, 2006, p.338.
} 
Studies. After the Iraq war, it was clear that the trial of U.S. oppressive policy to settle democracy was failed. U.S. failure in Iraq clarified that Middle Eastern countries didn't accept the idea of "pure" Western-rooted democracy. Yet, at the same time, fitting domestic economy to liberal economy and to achieving coexistence Islam and democracy became agendas for most of Middle Eastern countries. In such situation, Turkey is gradually emerging as successful example of democracy, liberal economy and compatible between Islam and democracy. Turkey has experienced multi-party system since 1950, and has improved its democracy along with EU's initiatives since 1999. In 1980s, thenPrime Minister Turgut Özal introduced liberal economy into Turkish economy based on import substitution policy at that time. Especially, Justice and Development Party (JDP), which has been single ruling party since 2002, has advanced Europeanization, liberal economy and balance between Islam and democracy. After the Iraqi War happened, JDP tries to be "norm entrepreneur" and "norm transmitter" in the Middle East. Turkey can transmit the norms and ideas which are acquired from the European Union and the United States or developed its own way to the Middle East countries. Western norms are interpreted or localized with Turkey's traditions, and these norms may spread to other Middle East countries through bilateral negotiations or meeting of the regional organizations.

The aim of this paper is to explore how Turkey tries to spread norms toward the Middle East region. For examining this issue, paper can be roughly divided into two parts. First part is to summarize the theoretical part of norm issue and its diffusion, especially constructive perspective. Second part is to examine Turkey's activities of norm diffusion during the JDP period. Democracy, liberal economy, and the balance between Islam and democracy are taken as norms for analysis. In conclusion, this paper evaluates the success and fail about Turkish norm spread trial in the Middle East region. 


\section{Typology of Norms and Norm Diffusions in International Relations}

\section{The Concept of Norm in International Relations}

According to Annika Bjorkdahl, the concept of norm in International Relations is classified into rational, sociological, normative and constructive perspectives. ${ }^{2}$ Rationalists regard norm as standards of behavior, regulated obligations and rights. This perspective treats norms like rule and emphasizes on the sanction for compliance bring power into analysis ${ }^{3}$. Sociological perspective defines norm as the regularities, the normal and the uniformities in behavior. Normative perspective is maybe most famous and popular definition in International Relations. Until the 1980s, norm matter had been mainly treated in the area of liberalism and tightly connected with the concept of moral. ${ }^{4}$ For liberalists, the idea of norm and institution is the countermeasure of power politics. ${ }^{5}$ Fourth perspective is constructivist one. The approach of constructivism is different from liberal one because constructivists has tried to research not only norm itself but also its transformation, the way of transformation, the trigger of

2 Annika Bjorkdahl, "Norms in International Relations: Some conceptual and methodological Reflections", Cambridge Review of International Affairs, Vol.15, No.1 (2002), pp.13-15.

${ }^{3}$ Ibid, p.14.

${ }_{4}$ Talking about the norm, naturally ethical or moral factor are included in this concept. Traditionally, enlightenment thinkers like Charles SaintPierre and Kant noticed on the important of norms for prohibiting war. After the establishment the academics of International Relations in 1919, norm issue was one of the most interesting matters for the idealists who aspired to be peace through League of Nations and to throw power politics away.

5 For example, Charles Beitz, Political Theory and International Relations, Princeton, Princeton University Press,1979; Stanley Hoffman, Duties Beyond the Borders: On the Limits and Possibilities of Ethical International Politics, Syracuse, Syracuse University Press, 1987. 
transformation, the impulse of transformation and diffusion process. ${ }^{6}$ For constructivist, norms are considered as a set of intersubjective understanding and collective expectations regarding the proper behavior of states and other actors in a given context or identity. In respect of norm diffusion analysis, constructivism perspective which takes account of norm transformation is useful. So, this paper generally uses the concept of norm from constructivism perspective.

Function of norms can be also divided into three types, regulative, constitutive and practical functions. ${ }^{8}$ Regulative norms mean order and rule for regulating behavior. Constitutive norms are giving the meaning to action and creating interest. Practical norms combine with regulative norms and constitutive norms, which are institutionalized and adapted to everyday life. Constructivists strongly focus on constitutive and practical functions because these approaches come along the room for interpretation and intersubjectivity.

\section{The Constructivists' Contributions of Norm Diffusion and its Process}

In the late 1980s, gradually some constructivist like John Ruggie, Friedrich Kratochwil, Alexander Wendt began to focus on norm issues. Although constructivists work in early 1990s stress that norm, culture and identity influence, these didn't show the different response of actors to these influences.

Some scholars like Jeffrey Checkel pointed out that the issue was not only the different responses of states to the same international norms, but also the different mechanisms of

6 Martha Finnemore and Kathryn Sikkink, "International Norm Dynamics and Political Change" International Organization, Vol. 52, No.4 (Autumn 1998), p. 888.

${ }^{7}$ Bjorkdahl, Ibid, p.15.

${ }^{8}$ Idem. 
internalized the international norms within the state. ${ }^{9}$ They focuses on struggle and change between transnational norms and local norms. Considering norm socialization, the existence of norm entrepreneurs who dissatisfy with existing norms and rules in politics, often band together and try to change or transform them is essential factor. ${ }^{10}$ Checkel, defines the phenomenon of norm diffusion as "By a standard definition, is the "transfer or transmission of objects, processes, ideas and information from one population or region to another": or, as one popular text puts it, diffusion occurs when an "innovation is communicated through certain channels over time among members of a social system". ${ }^{11}$ Thinking about the process of norm spread, norm transmitters are key player as well as norm entrepreneur.

With respect to norm spread, the important question is how these norms adapt and transform, and by what process. For answering these questions, this paper takes three approaches to which are presented by Ann Florini, Martha Finnmore and Kathayn Sikkink, and Amitav Acharya.

Florini tries to analyze the norm issue using evolutional theory as an analogy between genes and norms. According to her, norms can survive under conditions in which they are satisfactorily prominent in the norm pool, dependent on their relationships with other prevailing norms, and on the environmental conditions. Norm entrepreneurs like people or states promote the particular international norms in their own countries. ${ }^{12}$ Florini classified

9 Jeffrey Checkel, "The Constructivist Turn in International Relations Theory", World Politics, Vol.50 (1998), p.348.

10 Martha Finnemore and Kathryn Sikkink, "Taking Stock: The Constructivist Research Program in International Relations and Comparative Politics", Annual Review of Political Science, Vol.4 (2001), p.400.

11 Jeffrey Checkel, "Norms, Institutions, and National Identity in Contemporary Europe", International Studies Quarterly, Vol.43 (1999), p.85.

12 Ann Florini, "The Evolution of International Norms", International Studies Quarterly, Vol.40, No.3 (1996), pp.374-376. 
norm diffusion in two ways. The way of vertical reproduction is functionally a continuation of the norm. In this process, new generations try to fit the traditional norms. On the other hand, the way of horizontal reproduction primarily emulates norms. Fundamentally, horizontal reproduction can spread norms much more quickly because actors can select the fittest norm for their environment.

Although pointing out the conditions of norm diffusion, Florini does not precisely delineate the steps or modes of the processes of diffusion. Finnmore and Sikkink made up this defect. They showed three stages of norm process: norm emergence, norm cascade and internalization. In first stage, the activities of norm entrepreneurs and organizational platforms are the central factors. Norms are actively built by agents with strong notions of what is appropriate or desirable behavior in their communities. ${ }^{13}$ Their actions are directed toward keeping, changing or transforming norms when faced with the appearance of alternative to norm. Organizational platforms are also essential for emerging norms because norms are generally taken into through organizational platforms. ${ }^{14}$ The main method at this stage is persuasion or explanation. When norm entrepreneur has persuaded a critical mass of states to become norm leaders and adopt new norms, they call this situation as "tipping point" of the first stage. ${ }^{15}$ After the "tipping point", applicable actors start to adopt new norms rapidly with (or even without) domestic norm change. During this time, the concept of socialization is essential for norm transformation:

In the context of international politics, socialization involves diplomatic praise or censure, either bilateral or multilateral, which is reinforced by material sanctions and incentives. States, however, are not the only agents of socialization. Networks of norm

\footnotetext{
${ }^{13}$ Finnemore and Sikkink, 1998, Ibid, p.896.

${ }^{14} \mathrm{Ibid}, \mathrm{p} .899$.

${ }^{15} \mathrm{Ibid}, \mathrm{p} .901$.
} 
entrepreneurs and international organizations also act as agents of socialization by pressuring targeted actors to adopt new policies and laws and to ratify treaties and by monitoring compliance with international standards. ${ }^{16}$

Concerning socialization, state identity undergoes a noticeable change. The degree of the participation in the international sphere or events is an important factor in the change of states' identities. This is because the state receives pressure from other countries and international organizations in such situations. Thirdly, the stage of norm internalization is described as a powerful influence (behavior in accordance with the norm is not questioned) and is hard to discern (actors don't think critically over norms and their regulations). ${ }^{17}$ Finnemore and Sikkink emphasize the role of the norm entrepreneur here again. An entrepreneur, like professional in training, can become familiarized and take root among state and society. Legitimacy of norms in the international sphere is also an important factor for internalization. They especially emphasize the role of norm entrepreneur.

Acharya focused on the regional adaptation of international norms. He pointed out that many constructivists considered norm transformation as good global norms to prevail over bad local beliefs and practices. ${ }^{18}$ Against these discourses, he emphasizes the importance of indigenous norms and policies for reconstructing transnational norms after being faced with local norms. His key concept is localization, which is defined as the following:

Instead of just assessing the existential fit between domestic and outside identity norms and institutions, and explaining strictly dichotomous outcomes of

16 Ibid, p.902.

${ }^{17} \mathrm{Ibid}, \mathrm{p} .904$.

18 Amitav Acharya, "How Ideas Spread: Whose Norm Matters? Norm Localization and Institutional Change in Asian Regionalism", International Organization, Vol.58, No.2 (Spring 2004), p.239. 
acceptance or rejection, localization describes a complex process and outcome by which norm-takers build congruence between transnational norms (including norms previously institutionalized in a region) and local beliefs and practices. In this process, foreign norms, which may not initially cohere with latter, are incorporated into local norms. The success of norm diffusion strategies and processes depends on the extent to which they provide opportunities for localization. ${ }^{19}$

For Acharya, on the one hand, norm diffusion is viewed as a result of adaptive behavior in which local practices are made consistent with an external idea. On the other hand, localization is a process in which external ideas are simultaneously adapted to meet with local practice. Localization is progressive, and reshapes both existing beliefs and practices and foreign ideas in the local context. ${ }^{20}$ So this process contains an evolutional aspect.

For the process of localization and its condition, Acharya delineates four dimensions. The first phase is pre-localization (resistance and contestation). In this phase, local actors resist the new external norms and doubt their effectiveness. If they suppose the external norms may potentially contribute to their current norms, some local actors may begin to adopt or learn these norms. This is the starting point of norm localization. Though they begin to adapt or learn new norms, some existing norms remain strong. ${ }^{21}$ The second phase is Local initiative (entrepreneurship and framing). Local actors try to establish a framework within which to integrate the new external norms. ${ }^{22}$ If local society hails the new external norms, they may easily penetrate the new framework. The third phase is learning (grafting and pruning). External norms may be transformed to adapt with local norms and practices. External

${ }^{19} \mathrm{Ibid}, \mathrm{p} .241$.

${ }^{20} \mathrm{Ibid}, \mathrm{p} .252$.

${ }^{21} \mathrm{Ibid}, \mathrm{p} .251$.

${ }_{22}$ Idem. 
and local norms seek to find common ground for coexistence. In this process, selection is very important. But external norms are considered to be supplements to existing norms, not complete alternatives. ${ }^{23}$ The fourth phase is amplification and universalization. New systems and practices emerge from the syncretic normative framework in which local influences remain clearly visible. ${ }^{24}$ This step is the same as Finnemore and Sikkink's concept of socialization.

According to Acharya, there are three main forms of local responses to transnational norms. These are localization, resistance and norm displacement. ${ }^{25} \mathrm{He}$ insists that resistance makes no new tasks and instruments. Transnational norms and institutional models remain largely intact. Too much and sustained resistance leads to failure of norm transmission. Meanwhile, norm displacement creates new tasks and instruments. In addition, transnational norms are displaced and the norm hierarchy altered. Hence new institutions emerge, and transnational norm entrepreneurs play an important role in responding to these transnational situations.

Florini, Finnemore and Sikkink, and Acharya show and develop the explanation way of norm diffusion process. Florini emphasizes the norm selection and the direction of norm spread. Finnemore and Sikkink show the norm diffusion process and notice on the role of norm entrepreneur. Florini, Finnemore and Sikkink only focus on the spread of international norms, however, Acharya takes notice on the localization process. Hence, Acharya emphasizes not only the role of norm entrepreneur but also norm transmitter in regional or local sphere. "Norm transmitter" is defined not only as transmitting norms made by norm entrepreneurs, but also as adding its own influence through the transmission process.

$$
\begin{aligned}
& { }^{23} \text { Idem. } \\
& { }^{24} \text { Idem. } \\
& { }^{25} \text { Ibid, p. } 254 .
\end{aligned}
$$




\section{The Norm Diffusion and Turkey}

\section{Turkish Norm Diffusion and its Framework}

Why does this paper take notice on Turkey as an actor in norm diffusion? This is because Turkey takes charge of its norm entrepreneur and transmitter roles between the West and the Middle Eastern community. As norm entrepreneur, Turkey exports its estate planning for helping the development toward other countries or regions. TOBB's project of the series of Ankara forum toward the Palestine and Israel was a case of norm entrepreneur. In addition to this, Turkish demonstrative effect is also classified as norm entrepreneur. This is not some particular policies. And the perceptions of other countries are important elements for demonstrative effect. For Turkey's case, the growth of economy and per capita income and success of coexistence democracy and political Islam are powerful sources of demonstrative effect. ${ }^{26}$

\section{(Figure 1: Route of Norm Entrepreneur)}

Turkey as a norm entrepreneur

$\downarrow$ (Vertical/Horizontal )

Middle East countries and regions

26 Kemal Kirisci, "Diffusing liberal market and democratic values: Assessing Turkey's "soft power" in transforming its neighborhood", American Political Science Annual Meeting, 2-5 September 2010, p.11. Kirisci takes the growth of Turkish economy and per capita income, scholarship program, liberal visa policy, democratic promotion policies, and aid policies as demonstrative effects. But this article uses the word of demonstrative effect as uninvolved policies. 
As norm transmitter, Turkey received the norms from the norm entrepreneurs like the European Union and the United States at first. In other words, Turkey's Europeanization and cooperation with the United States are the first step of norm diffusion process. This process is clearly a top-down or vertical process. Turkish domestic norm adaptation is also important. Before Turkey tries to spread accepted norms, it has to transform these norms to fit easily into own context and those of the Middle Eastern countries. This is a secondary step of norm diffusion, which is defined as localized norms. The Turkish trial to spread localized norms to Middle Eastern countries is the third step of norm diffusion. Generally, in this process, Turkey uses regional organization, like the Organization of the Islamic Conference (OIC) and the Broader Middle East and North Africa (BMENA). As Finnemore and Sikkink describes, the international sphere or events are important for changing states' identities. Here, localized norms by Turkey are accepted more smoothly or partlytransformed (Middle Easternized) for adaptation.

What is the advantage of norm diffusion from Turkey to the Middle East Countries? When considering the norm diffusion toward the Middle East, especially democracy, we can find three modes. The first mode is the approach directly pushed by European countries and the US. This way has not worked well due to rising anti-Americanism, especially after the 2003 Iraq War. The second mode is using so-called moderate Arab countries, like Saudi Arabia to promote democracy. This mode is also vulnerable for norm diffusion because these moderate countries also aren't satisfied with the norm. It is because Saudi Arabia is a monarchy and dissatisfies democracy itself. The third mode is using Turkey. Surely, the Arab people still carry some resentment against Turkey because of their domination during the Ottoman period. But comparative to that of the Cold War period, this tendency is decreasing. Hence, Turkey may be suitable to be a norm transmitter in the Middle East region. 
Turkey's Norm Diffusion Policies toward the Middle East

(Figure 2: Route of Turkey's Norm Transmitter Role)

$$
\begin{aligned}
& \text { EU - United States } ・ \cdot \text { Core norm entrepreneurs } \\
& \downarrow \text { First step of norm diffusion } \\
& \downarrow \text { (Vertical) } \\
& \text { Turkey • • • Second step of norm diffusion }
\end{aligned}
$$

(Domestic adaptation \& norm localization)

\author{
$\downarrow$ \\ Regional Organizations $\cdot \cdot \cdot$ Platforms of norm diffusion \\ (OIC, BMENA) Third step of norm (localized norm) \\ diffusion \\ $\downarrow$ \\ Middle East Countries
}

\title{
Turkey as a Norm Entrepreneur
}

\section{Case of Ankara Forum}

To improve the relations between Israel and Palestine, Turkey was prepared to organize conferences, create an economic zone, and maintain bilateral relations with each country. This can be described as one of the success stories of public diplomacy and norm entrepreneur with support from Turkish government. ${ }^{27}$ According to TOBB's report on the Ankara Forum, TOBB undertook a series of Ankara Forums beginning on November

27 Interview with Esen Çağlar in TEPAV, 7 April 2011. Until 2005, generally speaking, the Turkish government did not privide aid to bussiness activities in the Middle East. Hence Turkish business activities toward the Middle East were not organized and lacked certain mechanisms. 
$2003{ }^{28}$ TOBB sent letters to the Manufactures Association of the Israeli and Palestinian Chambers of Commerce, Industry and Agriculture regarding cooperation in the implementation of the Ankara Forum. On the other hand, TOBB established the Economic Policy Research Foundation of Turkey (TEPAV) as a supporting institution for its economic policies toward neighboring region. ${ }^{29}$ First of all, TOBB held meetings for economic cooperation with Turkey, Israel and Palestine in Ankara on 27-28 April 2005. ${ }^{30}$ Rifat Hisarcikloğlu, President of TOBB, Shraga Brosh, CEO of the Manufactures Association of Israel, and Ahmed Hashem Al-Zugahir, president of Palestinian Chambers of Commerce, Industry and Agriculture, discussed the possibility of economic cooperation between Palestine-Israel-Turkey. The first Ankara Forum declared its objective "to be enabling business people's contribution to the peace building process in Palestine

28 "Ankara Forum (Bilgi Notu)", 21 Aralik 2010 Türkiye Odalar ve Borsalar Birliği <bttp://wmw.tobb.org.tr/AvrupaBirligiDairesi/Dokumanlar/ Faaliyetler/ankaraforumu/ankara forumu.pdf>, (access date 3 February 2011).

29 TEPAV is an independent and non-partisan think tank. Regional integration activities are one of the pillars of TEPAV. Other than Ankara Forum, TEPAV implemented the expansion of business association networks and the Istanbul Forum with Afghanistan and Pakistan. Esen Çağlar, "Turkey's economic transformation and role of organized industrial zones", 5 April 2010, <http://wmw.ecocci.com/DC/PDF/ 19.04.201017_38Presentation\%200n\%200IZ.pdf>, (access date 20 March 2011).

30 Bülent Aras, "Turkey and the Palestinian Question", SET A Policy Brief, No.27 (2009), p.5. According to Esen Çağlar, economic expert for TEPAV, the year 2005 was important to start the Ankara Forum. Turkey recovered its economy from the 2001 financial crisis, and began to commit to international economic integration. In addition, Turkey appealed to its starategic importance toward the Middle East with respect to the EU. These situations backed up the project of Ankara forum. Interview with Esen Çağlar in TEPAV, 7 April 2011. 
through feasible projects". ${ }^{31}$ Specifically, the three associations aimed to remove obstacles to economic relations between Palestine and Israel in order to achieve security and stability between the two countries through the development of economic relations. ${ }^{32}$ They also planned to cooperate in the areas of tourism, industrial investment, infrastructure, free movement of goods, and education. ${ }^{33}$ Industrial investment in Erez industrial zone and tourism were main topics at subsequent second to fifth meetings.

At the second meeting held in Jerusalem on 8 June 2005, the organizations decided to set up working groups for the activation of tourism and the Erez Industrial Zone. ${ }^{34}$ This was the Turkey's domestic successes and experiences of organized industrial zones projects to apply other countries. ${ }^{35}$ TOBB Industrial Park Management Company (TOBB-BIS) has undertaken the trilateral project. TOBB-BIS founded in November 2005 is the company which is "to develop and manage industrial and technology parks in Turkey and Turkey's surrounding region". According to its own report, the aims of TOBB-BIS are "to transfer the know-how of Turkish chambers to countries around Turkey in developing and

31 "Ankara Forum for Economic Cooperation between Palestine, Israel and Turkey Meeting Held", 27 April 2005, <http://wnww.tepav.org.tr/ en/haberler/s/1900>, (access date 3 February 2011).

32 "İsrail ve Filistinle ticareti artıralım barışa katkı yapalım", Hürriyet, 28 Nisan 2005.

33 "Ankara Forum for Economic Cooperation...", Idem.

34 "Ankara Forum 2 for Economic Cooperation Between Palestine, Turkey and Israel", 8 June 2005, <http://www.tepav.org.tr/ en/haberler/s/1009>, (access date 3 February 2011). The members of working group of the Erez Industrial Zone were Güven Sak, Samir Y.S. Hazboun, and Dan Catarivas.

${ }^{35}$ Interview with Esen Çağlar in TEPAV, April 7, 2011. Until 2010, there were 258 authorized organized industrial zones in Turkey, and 120 of which were fully working. Local chambers play important role to activate organized industrial zones. Cağlar, Ibid. 
managing industrial and technology parks". ${ }^{36}$ Another major goal is "to act as a catalyst in private sector development, while opening new avenues of growth for Turkish companies".

Organized industrial zones in domestic politics were promoted after Özal's economic reform and newly emerging middle class. However transferring its knowhow, TOBB launched projects dependent on businessmen's requests and countries' situations.

According to Third Ankara Forum held in Istanbul on 2021 September investment insurance and promotion activities in Erez Industrial Zone, as well as development processes in tourism sector were the main items of discussion. ${ }^{37}$ The establishment of 200 companies with 6000 Palestinian people to be employed after establishing stability in the region was a plan suggested for the Erez Industrial Zone. ${ }^{38}$ The fourth Ankara Forum, which was held in Tel Aviv on 15 January 2007 more than one year after the previous forum, focused on the importance of continuity in cooperation. At TOBB's initiative the fifth Ankara Forum was held in Washington DC on 30 March 2007. This meeting was meaningful because the US strongly backed the forum. In addition to US support, employment in the Erez Industrial Zone was due for upward revision from 2000 to $10000 .{ }^{39}$ The sixth meeting held

36 "TOBB-BİS: Industrial Parks Management Company" <http://mmn.industryforpeace.org/TEPAV February 2011).

37 "Joint Declaration of the $3^{\text {rd }}$ Meeting of the Ankara Forum", 20-21 September <http: // www.tepav.org.tr/upload/files/haber/1255425530r1448. Ankara_Forumu_3_Deklerasyon.pdfs, (access date 4 February 2011).

38 "Türkiye, Gazze'de 6 bin Filistinliye iş sağlayacak", Zaman, 22 Eylül 2005. TOBB does not limit organized industrial zone sector. All sectors can enter this project, if they wish. Interview with Esen Çağlar in TEPAV, 7 April 2011.

39 "Washington Declaration of the Ankara Forum", 30 March 2007, < bttp:/ / www.tepav.org.tr/upload/ files/ haber/1282035658-3.Washington_ Declaration.pdf>, (access date 4 February 2011). 
in East Jerusalem on 4 September launched a new project in the West Bank in parallel with the Erez Industrial Zone. ${ }^{40}$

In the seventh meeting held in Ankara on 13 November 2007, three chambers of commerce proceeded in the project of the West Bank Industrial Zone. These were (i) the project of the West Bank Industrial Zone, which would be started in the Tarkumya region by the Palestine government, (ii) the government should approve the project, and the TOBB-BIS companies should develop and acquire management status of the project, (iii) the Israeli government would sign a protocol on security for Palestinians and the passage of goods from Palestine, (iv) Israel would manage water and electricity infrastructure. ${ }^{41}$

As discussed above, the Ankara Forums led by three business councils produced an opportunity for dialogue between Palestine and Israel, and for cooperation between three countries on a business area. Job creation for Palestinians was a particularly useful way to reduce poverty and prevent terrorism toward Israel. Undoubtedly, this trilateral forum is an important initiative for achieving prosperity. Güven Sak emphasizes the uniqueness of the Ankara Forum's "plug away" approach to solving essential problems. According to him, the characteristics of approach are (i) well-functioning public-private dialogue mechanisms, (ii) concrete and local projects, (iii) interim solutions, (iv) engagement in

40 "Joint Declaration of the Sixth Meeting of the Ankara Forum", 4 September 2007, <http://www.tepav.org.tr/upload/files/haber/ 1252654505r8838.Joint_Declaration_of_the_Sixth_Meeting_of_the_Ankara_ Forum_East_Jerusalem.pdf $>$, (access date 4 February 2011).

41 In seventh meeting, members of Ankara Forum and the Turkish government succeeded in facilitating a meeting between Israeli president Shimon Peres and Palestinian President Mahmoud Abbas. This meeting was positioned as a crucial step toward the Annapolis summit held on 26-28 November in Annapolis. In other words, the Ankara Forum played a role as a platform of Palestine-Israeli meeting. 
transformational diplomacy. ${ }^{42}$ Projects of organized industrial zones have broadly granted three benefits to Palestine. These are (i) to attract foreign companies, (ii) to cut the cost of labor, and (iii) to brush up the skills of Palestinians. ${ }^{43}$ These benefits contribute not only to the activity of the economy, but also to help create a peaceful situation in the region. The project of exporting the knowhow about industrial zone is typical norm entrepreneur policy. Turkey tries to export the project which is success in domestic politics. TOBB also launched Istanbul Forum, which aims to cooperate with Afghanistan and Pakistan, and promotes industrial zone project to Afghanistan.

\section{Case of Turkish Model}

When political changes happened in Tunisia and Egypt well known as "Arab Spring", Turkey's prestige in the Middle East region is drawn attention as "Turkish model", which mixed political Islam with democracy and liberal economy. In Egyptian case, at first, Prime Minister Erdoğan demanded President Hosni Mubarak to implement the reform in domestic politics. But the end of January, Turkish government changed its policy from urging reform to demanding the resignation of Mubarak. ${ }^{44}$ Turkish government cautiously took care of the international public opinion to keep its prestige in the Middle East. For example, in

\footnotetext{
42 Güven Sak, "TOBB Indutry for Peace Initiative: Revitalization of the Palestinian Industrial Free Zone", 25 April 2006, <bttp:// www.tepav.org.tr/upload/files/ haber/1252506452r5390.TOBB_ Industry_for_Peace_Initiative_Revitalization_of_the_Palestinian_Industrial_Free_ Zone.pdfs, (access date 6 February 2011).

${ }^{43}$ Interview with Esen Çağlar of TEPAV, 7 April 2011.

44 "Turkish PM Erdoğan urges Mubarak to heed Egyptian outcry", Hürriyet Daily News, 1 February 2011; "Türkiye nihayet Misır konusunda sessizliğini bozdu”, Hürriyet 1 Şubat 2011.
} 
mid-September, Erdoğan visited to Egypt and Tunisia, and welcomed as a leader of great activity. ${ }^{45}$

Regarding contemporary Arab perceptions toward Turkey, the Turkish Economic and Social Studies Foundation (TESEV) published substantial surveys. The first one was the report "Perception toward Turkey in the Middle East" published in 2009. A survey was administered amongst the people in Egypt, Iraq, Jordan, Lebanon, Palestine, Saudi Arabia, Syria and Turkey, and some items are striking. The questions of "Whether Turkey should take a more effective role in Arab world or not?", and "To what degree can Turkey contribute to peace in the Middle East?", Turkey received high rates of approval and trust from Palestine and Syria. ${ }^{46}$

The question of "model of democracy" is very compelling. Frankly speaking, the discussion of the "Turkish model" has two faces. The first face is the Kemalist model of secularism. The second model is the blending of Islam and democracy that emerged during the AKP period. Concerning first model, perceptions of people in Arab countries were not so high. The highest rate was $73 \%$ in Palestine, and the second highest rate of approval was $72 \%$ in Syria. ${ }^{47}$ Turkey also received high rates from Palestine $(74 \%)$ and Syria $(72 \%)$ on the question of "Whether Turkey is a model mixture between Islam and democracy or not?". ${ }^{48}$ In comparison with the secularist model, the mixture model received somewhat higher rates of approval from surveyed countries, except from Iraq (51\%). In conclusion, this report

45 "PM to give Turkey as example to region", , Hürriyet Daily News, 12 September 2011. Concerning the Arab Spring and Turkish model, see Şaban Kardaş, "Turkey and the Arab Spring: Coming to Terms with Democracy Promotion", Policy Brief, Washington DC, The German Marshall Fund.

${ }^{46}$ Mensur Akgün, Gökçe Perçinoğlu, and Sabiha Seyücel Gündoğar, Orta Doğu'da Türkijye Algisı, Istanbul: TESEV Yayınları, 2009, pp.18-20.

${ }^{47} \mathrm{Ibid}, \mathrm{p} .21$.

${ }^{48} \mathrm{Ibid}$, p.22. 
revealed that Arab countries generally evaluated Turkey as a positive player in the Middle East, and do not look upon Turkey as a hegemonic force or threat in the region. ${ }^{49}$

TESEV published the same report in 2010. The average rate of approval on the question of "Whether Turkey would become a model for Arab countries or not?" rose from $61 \%$ in 2009 to $66 \%$ in 2010, and "Whether Turkey is a mixture model between Islam and democracy or not?" also rose from $63 \%$ to $66 \%{ }^{50}$ In the 2010 version, TESEV gathered the reasons of "why Turkey can become a model?". The main reasons were that it was a Muslim country $(15 \%)$, that it was an economic success $(12 \%)$, the mixture of democracy and Islam (11\%), and the response to Palestine issues. ${ }^{51}$ Meanwhile, all those countries began to withdraw support from the ideas of Turkish EU accession. The influence of Turkey's EU membership on Middle East politics also decreased from $64 \%$ to $57 \% .{ }^{52}$ Concerning the "Turkish model", the Arab publics considered not the model of secular state but the model of an economically Muslim democracy to be their goal. As Meliha Altunışık commented, Arab perceptions are changing both at the state and public levels. ${ }^{53}$ According to these two reports, Arab perceptions toward Turkey were basically positive, a big change compared against public opinion of the Cold War and early post-Cold War periods. Turkish image is changing or has changed from that of the "terrible Turk" to "the model based on Islam, democracy and economy".

\footnotetext{
${ }^{49} \mathrm{Ibid}, \mathrm{p} .26$.

50 Mensur Akgün, Gökçe Perçinoğlu, Jonathan Levack and Sabiha Seyücel Gündoğar, Orta Doğu'da Türkiye Algısı, Istanbul: TESEV Yayınlar1, 2011p.12.

${ }^{51} \mathrm{Ibid}, \mathrm{p} .13$.

52 Ibid, p.14.

53 Meliha Benli Altunış1k, Turkey: Arab Perspectives, Istanbul: TESEV Publications, 2010, p.14.
} 


\section{First Step of Norm Diffusion as a Transmitter}

The route of norm diffusion through Europeanization process in Turkey begins in the EU and moves toward Turkey. Westernization process in Turkey started with the establishment of the Republic of Turkey in 1923 under Kemal Atatürk. But the Kemalist incarnation of Westernization was a state-centric imitation of European and American processes, so norm transformation or localization of norms was not as successful as hoped. Hakan Yavuz describes Kemalist Westernization as superficial, and draconianly imposed, modes of dress and decorum, and he insists that they failed to absorb the ideals of pluralism, democratic governance, and a form of secularism that allowed individuals to pursue their freedoms of conscience. ${ }^{54}$ This situation has clearly changed after the Helsinki summit in 1999, at which the European Council declared that Turkey was a candidate to join the EU, based on the same criteria as applied to all other applicants. This decision encouraged Turkey to change its attitude toward the EU, especially the young pro-Islamic generation led by the likes of Erdoğan and Gül. Since coming to power, AKP has aggressively tried to advance its EU agenda. In 2002, the Copenhagen Summit was held, and Turkey began to reform its domestic policies to fit EU criteria. In December 2004, Turkey at last was granted the right to begin accession negotiations with the EU.

"Europeanization process introduces new rules, norms, practices, and structures of meaning to which member states are exposed and which they have to incorporate into their domestic practices and structures". ${ }^{55}$ For accession to EU, constitutional

54 "Islam and Europeanization in Turkish-Muslim socio-political movements" in Timothy A. Byrnes and Peter J. Katzenstein (eds), Religion in an Expanding Europe, Cambridge: Cambridge University Press, 2006, p.229.

55 Tanja A. Borzel and Thomas Risse, "Conceptualizing the Domestic Impact of Europe" in K. Fetherstone and C.Radaelli (eds), The Politics of Europeanization, Oxford: Oxford University Press, 2003, p.66. 
amendments were implemented in 2001 and 2004. On 12 September 2010, national referendum whether 1982 constitution would be changed or not was implemented, and passed by $58 \%$ support. ${ }^{56}$ In addition to constitutional amendments, Turkey implemented EU harmonization packages to satisfy EU's acquis communautaire. From $1^{\text {st }}$ to $6^{\text {th }}$ harmonization packages, it focused on the improvement of minority lights. After $7^{\text {th }}$ harmonization package, to diminish military privileges is main reform agenda.

After the end of the Iraq War, many U.S. high level politician and scholars often mentioned that Turkey could be model of democratization in the Middle East region. For example, Paul Wolfowitz, the deputy secretary of defense in that time, described both disappointment of Turkish behavior in Iraq War and expectation of Turkish behavior as democracy model in the Middle East:

Our strategic partnership has changed. It is no longer as it was before. In the past, this relationship was based on a military basis. Only military relations used to be discussed. This era is now closed. Military relations of course do exist but the new strategic partnership is not based on a military field but rather on democracy and politics. ${ }^{57}$

Advancements based on EU accession are relevant to these discourses. Turkish accession to the EU might contribute to Middle Eastern stability and to a secular, modern and democratic

56 “Türkiye Anayasa değisikliğini “evet” dedi”, Hürriyet, 12 Eylul 2010.

57 Mehmet Ali Birand "Turkish-US strategic cooperation changing", Turkish Daily News, 31 January 2004. In here, Birand supplemented with comment as "Turkey is now the new favorite of the Bush administration. Turkey is the sole example of the co-existence of Islam and democracy. Turkey, until recently, was a country that drew attention because of its geographical location. Now, its democracy is in the spotlight". 
form of governance. ${ }^{58}$ The AKP is the main norm accepter and entrepreneur for Europeanization within Turkey. Europeanization has partly encouraged human rights, liberal economy, and democracy in order to shift the country to a more democratic course.

\section{Second Step of Norm Diffusion (Localization of Norm) as a Transmitter}

"Conservative democracy" suggested by AKP government as political tool in both domestic and foreign policies. This idea was defined by Yalçın Akdoğan, advisor to Prime Minister Erdoğan. According to him, conservative democracy has three features. ${ }^{59}$ First of all, the foundation of this concept is the culture of reconciliation. Metin Heper explains culture of reconciliation as "the maxims given above indeed aims at a successful reconciliation of past and present, tradition and modern, religion and state, society and state, Islam and democracy, conflict and consensus, order and freedom, morality and rationality, and global and indigenous". 60

Secondly, the idea of conservative democracy does not accept authoritarianism and totalitarianism. Thirdly, the legitimacy of conservative democracy is based on popular sovereignty and the rule of law. Regarding the concept of conservatism, Akdoğan described it in the following way:

58 Kemal Kirişci, "Between Europe and the Middle East: The Transformation of Turkish Policy", MERIA, Vol.8, No.1 (2004), p.39.

${ }^{59}$ Yalçın Akdoğan, "The Meaning of Conservative Democratic Political Identity" in Hakan Yavuz (ed), The Emergence of $A$ New Turkey: Democracy and the AK Parti, Salt Lake City: University of Utah Press, 2006, p.50.

${ }^{60}$ Metin Heper, "A Democratic-Conservative Government by Pious People: The Justice and Development Party in Turkey" in Ibrahim M. Abu-Rabi (ed), The Blackwell Companion to Contemporary Islamic Thought, Oxford: Blackwell Publishing, 2006, p.351. 
However, by making conservatism the engine of change, the AKP has broken new ground in the history of Turkish politics. Furthermore, before the AKP, conservatism had not manifested itself in parties that stressed tradition, religion, social values, and the spiritual. ...In Turkey, conservatism is generally posited as a "political attitude" that insists on gradual change and the perpetuation of moral and family values....Conservatism as the AKP envisions it would play a positive role precisely because of its emphasis on conservative and gradual, rather than revolution and destructive, change. ${ }^{61}$

It is said that the member of the AKP considers its ideas and activities to be similar to those of the Democratic Party led by Adnan Menderes and the Motherland Party led by Turgut Özal, not to Islamic Parties led by Necmettin Erbakan. ${ }^{62}$ Morality, family and ordinary change were the core sources of the Turkish version of conservatism based on Ottoman history and the idea of Islam. ${ }^{63}$ The tight-knit of family was important rather than the individualism associated with the European lifestyle. The glorious Ottoman history, which was deemphasized by Kemalist circles still affected people's cultural lives and ideas. The idea of Islam shared among Muslim was an effective catalyst for community-building. The AKP government considers these communities to be the

${ }^{61}$ Akdoğan, Ibid, pp.53-55.

${ }^{62}$ Meanwhile, some scholars, like Ergün Yildirim, Hüsamettin İnaç, and Hayrettin Özler, point out that the Democratic Party and AKP have similar idea about social activity in society. But the DP's leadership came from ruling elite. On the other hand, the AKP's leadership is rooted in the lower- and middle-classes. This is a big difference between the Democratuc Party and AKP. Ergün Yildirim, Hüsamettin İnaç, and Hayrettin Özler, "A Sociological Representation of the Justice and Development Party: Is it a Political Design or a Political Becoming?", Turkish Studies, Vol.8, No.1 (2008), p.11.

${ }^{63}$ Hakan Yavuz, Secularism and Muslim Democracy in Turkey, Cambridge: Cambridge University Press, 2009, pp.93-96. 
device of prevailing democracy and gathering votes in an election. Turkish conservatism which was imposed on the cultural dimensions of individual life seems to coexistence with a state-led Westernization project until now. ${ }^{64}$

Erdoğan suggests that conservative democracy incorporates universal values and serves as a source of contribution toward other countries. ${ }^{65}$ As a synthesis between liberal and conservative thoughts, conservative democracy has consistency with the Europeanization process. This relationship also contributes to the transformation of both the Kemalist state structure and the demands of Islamist circles. ${ }^{66}$ One of AKP member described conservative democracy as "the outcome of the transformation of political Islam in Turkey with two key factors: the February 28 process and the Copenhagen criteria". ${ }^{67}$ Probably the most important point is that conservative democracy became an effective method for a pragmatic approach toward good relationships with the United States and the EU.

\section{Third Step of Norm Diffusion as a Transmitter}

Recently, Arab countries are interested in Turkish Europeanization reform as a reference. ${ }^{68}$ Regarding AKP policy, Davutoğlu highlights three characteristics of diplomacy toward the Middle East. First one is its "zero problems with neighbors"

\footnotetext{
${ }^{64}$ Ibid, pp.83-84.

${ }^{65}$ Erdoğan, “Conservative Democracy...", Ibid, p.337.

66 Burhanettin Duran, "JDP and Foreign Policy as an Agent of Transformation" in Hakan Yavuz (ed), The Emergence of A New Turkey: Democracy and the AK Parti, Salt Lake City: University of Utah Press, 2006, p.296.

${ }^{67}$ Yavuz, 2009, Ibid, p.93.

${ }^{68}$ According to TESEV's report, people in Lebanon, Palestine, and Syria regard Turkey's EU accession as positive to their own countries (positive answers were more than 70\% in 2009 and more than $60 \%$ in 2010). Mensur Akgün etc, 2010, Ibid, p.14.
} 
mantra which motivates Turkey to maintain good relations with neighboring countries. ${ }^{69}$ The second one is institutionalized regional engagement, like the activities in the Organization of the Islamic Conference (OIC), the initiative of Iraq's Neighbors Forum, and the Broader Middle East and North Africa (BMENA). The third one is its third party role in the region, especially the relationship between Syria and Israel. ${ }^{70}$ This paper focuses on the second approach, institutionalized regional engagement for norm diffusion, especially the Democracy Assistance Dialogue (DAD) in BMENA and activities in OIC.

\section{Case of DAD}

BMENA was a spotlight for promotion of Turkish democracy in the Middle East region after the Iraq War. ${ }^{71}$ The idea

69 As genera perspectives, Davutoğlu insists five principles: balance between freedom and security, zero problem policy, relationship with neighboring countries and beyond, multi-dimensional and multi-track diplomacy, and rhythmic diplomacy. Ahmet Davutoğlu, "Turkey's Foreign Policy Vision: An Assessment of 2007”, Insight Turkey, Vol.10, No.1(2008), pp.79-84.

${ }^{70}$ For a detailed account of the Turkish third party role, see Meliha Benli Altunış1k, "The possibilities and limits of Turkey's soft power in the Middle East", Insight Turkey, Vol.10, No.2 (2008), and Gürkaynak Esra, "Turkey as a third party in Israeli-Palestinian conflict: Assessment and Reflections" Perceptions (Spring 2007).

${ }^{71}$ Concerning the detail of BMENA, see Hüseyin Bağc1 and Bayram Sinkaya, "The Greater Middle East Initiative and Turkey: The AKP's perspective" in N. Goren and A. Nachimani (eds), The importance of being European: Turkey, the EU, and the Middle East, Jerusalem: The European Forum at Hebrew University, 2007; Meliha Altunıssk, "The Turkish Model and Democratization in the Middle East", Arab Studies Quarterly, Vol.27, No.1\&2 (2004); Nuri Yurdusev, "The Greater Middle East Initiative and Democracy in Muslim States: A Turkish Perspective", The Korean Journal of Defense Analysis, Vol.XVIII, No.2 (2006). And concerning the history and basic principle about BMENA, see Jeremy Sharp, "The 
of BMENA was based on the promotion of democracy and good governance, building a knowledge-based society, and expanding economic opportunities, which were discussed at the 2002 Arab Human Development Report. ${ }^{72}$ The specific plan of BMENA was clarified in the London-based Arabic newspaper Al Hayat on 13 February 2004..$^{73}$ Between 8 and 10 June 2004, BMENA was officially established at the G8 summit meeting on Sea Island, Georgia.

DAD was created at the first forum of BMENA in Rabat in December 2004 with the plans of establishing regional-specific enterprise and a microfinance training center. ${ }^{74} \mathrm{DAD}$ was one of the central activities of BMENA, and Turkey became the sponsor of this initiative, along with Italy and Yemen. The aims of this activity were (1) to coordinate and share information and lessons learned through democratic programs in the region. But DAD considered the situation and circumstance of each country, and cooperated with local ownership, (2) to work to enhance existing democratic programs or initiate new programs, (3) to provide opportunities for participants to develop joint activities, (4) to promote and strengthen democratic institutions and processes, and capacity buildings, (5) to foster exchanges with civil society groups and other organizations working on programs in the region.

To achieve this aim, TESEV became one of major civil society groups, along with No Peace Without Justice in Italy and the Human Rights Information and Training Center in Yemen.

Broader Middle East and North Africa Initiative: An overview", CRS Report for Congress, 2005.

72 Arab Human Development Report 2002, New York: United Nations Publications, 2002, < <ttp://hdr.undp.org/en/reports/regional/ arabstates /RBAS_abdr2002_EN.pdf>, (access date 15 May 2011).

73 "U.S. Working Paper For G-8 Sherpas", Al Hayat, 13 February 2004.

${ }^{74}$ Jeremy Sharp, Ibid, p.5.

${ }_{75}$ "Democracy Assistance Dialogue (DAD)", $<$ bttp:// hritc.net/en/index.php?action = show Sub Section Eid $=11>$, (access date 27 December 2011) 
Before establishing the BMENA, Turkey hosted the "platform for Democratic Governance in the Islamic World" in Istanbul in April 2004. At this conference, tolerance, justice, and participation were the main topics of discussion. Regarding democracy, three things were decided. These were (i) democratic decision-making processes that encourage the equal participation of men and women, (ii) accountable political parties that represent citizens' interests, and legislatures that are legitimized through democratic and transparent elections and genuine political competition, and (iii) a system of democratic governance that seeks to prevent corruption and strengthen the rule of law through mechanisms of transparency and accountability, freedom of information, and parliamentary and independent civil society. ${ }^{76}$

For promoting democratization in the BMENA region, TESEV and affiliated experts made three recommendations to the Turkish government: (i) to promote the monitoring and benchmarking to democracy within the region, (ii) to urge the participation of NGOs and to exchange experiences at the bureaucratic level, and (iii) to establish a democracy fund to support civil society and its regional networks. ${ }^{77}$

With respect to the DAD program, Turkish government and TESEV particularly focused on the empowerment of women, and held symposiums in Istanbul and Ankara to this end. Turkey focused the improvement of women's position. Both constitutional amendments implemented in 2001 and 2004 included the reinforcement equality between men and women. At 2001 amendment, "the equality between spouses in family" was decided. At 2004 amendment, "Men and women have equal rights. The state shall have the obligation to ensure that this equality

76 "Platform for Democratic Governance in the Islamic World", 14 April 2004, <http://2005-2009-bmena.state.gov/rls/55661.htm>, (access date 15 May 2011).

77 Burak Akçapar, Mensur Akgün, Meliha Altunışık, and Ayşe Kadıŏlu, The Debate on Democratization in the Broader Middle East and North Africa; $A$ Civic Assessment from Turkey, TESEV, 2004, pp.21-22. 
Turkey's Norm Diffusion Policies toward the Middle East

exists in practice". ${ }^{78}$ TESEV attempted to strengthen network within the BMENA region to solve the basic problems of women, including illiteracy, economic inequality, and lack of human rights. At the first symposium held in Istanbul on 20-21 June 2005, the discussed issues were how to relieve societal pressure related with the religion, family and some biases, how to urge empowerment to women, how to stop violence against women, and how to the need for the socio-economical welfare of women. ${ }^{79}$ The main issue discussed at the second Istanbul symposium was to promote the United Nations Convention of Discrimination Against Women (CEDAW). The third symposium held in Ankara on 22-23 May 2006 concluded with an agreement that DAD would aim to establish a regional Gender Institute. ${ }^{80}$ Eventually, BMENA's effort failed because of rising anti-Americanism and the chaos of Iraqi situation. The BMENA was US-initiated organization. Yet, TESEV continued its attempts to establish a regional gender institute in the broader Middle East and North Africa region. According to the TESEV's report, the main aims of the gender institute were (i) to gather data about gender to promote research, (ii) to build a network with civil society in the BMENA region, (iii) to establish a training center and a center for gender studies, (iv) to create a platform for advocacy and lobby action. ${ }^{81}$ To establish a gender institute in the BMENA region has not been realized until

\footnotetext{
78 "The Constitution of the Republic of Turkey", <http://mmn.anayasa.gov.tr/images/_loaded/ pdf_ dosyalari/ THE_CONSTITUTION_OF_THE_REPUBLIC_OF_TURKEY.pdf $>$, (access date 27 December 2011).

79 "Democracy Assistance Dialogue: Women's Empowerment in the Broader Middle East and North Africa, 2005-2006 Conference Almanac", <bttp:/ / mww.isn.ethæ.ch/isn/Digital-Library/Publications/Detail/ ?ots591= 0c54e3b3-1e9c-be1e-2c24-a6a8c7060233\&lng=en\&id=92479>, (access date 15 May 2011), pp.6-12.

${ }^{80} \mathrm{Ibid}, \mathrm{p} .35$.

81 "Feasibility Study: For a Broader Middle East and North Africa Gender Institute", October 2009, < <ttp://mwn.tesev.org.tr/UD_OBJS /PDF/DPT/OD/YYN/9930genderENGkitapWebicin.pdfs, (access date 15 May 2011), p.14.
} 
now, although Turkey and TESEV still continue to this project despite the end of the BMENA project.

\section{Case of OIC}

The relationship of the OIC and Turkey started from 1969, when Turkey decided to participate in the OIC. Historically, Turkey sometimes positively committed to the activities of the OIC. It did so, for example, after the Arab-Israel War in 1973, and during the period of Motherland Party government. ${ }^{82}$ But the relationship was limited to its economic aspect, like the Standing Committee for Economic and Commercial Cooperation (COMCEC). Yet, this situation changed and Turkey began to contribute to political dimensions of OIC after 2000s.

Firstly, Turkey participated in the OIC and EU Joint Forum on 12-13 February 2002. At that time, the Democratic Left Party was the ruling party and foreign minister Ismail Cem realized OIC-EU Joint Forum. Ecevit and Cem tried to create an opportunity for dialogue and reconciliation between the West and Muslim countries. These efforts were taken over by the AKP, and its policy of conservative democracy proved fitter than that of DSP.

Secondly, Turkish candidate Ekmeleddin İhsanoğlu won the election for the position of Secretary General of the OIC at the Istanbul OIC foreign ministers' summit in June 2004. To this end, Turkey has transmitted its message of internality and externality comfortably compared against its experience in other periods. Also, the Istanbul Declaration, a resolution in pursuit of democratic government, was signed in this summit. This was the first open election in the OIC. Like with the AKP's conservative

${ }^{82}$ For details the relationships between Turkey and OIC, see Mahmut B. Aykan, Turkey's Role in the Organization of the Islamic Conference: 1960-1992: The Nature of Deviation from the Kemalist Heritage, New York: Vantage Press, 1994. 
democracy, İhsanoğlu insisted on harmony and reconciliation. For example, he insisted the importance of dialogue in UN high level dialogue on inter-religious and inter-cultural cooperation for peace on 5 October 2007:

Dialogue is the only way to understanding. It is indispensable in building bridges and as a means of communication between religions and cultures. It is a must in promoting awareness to the necessity of understanding, confidence building, and ushering the world toward peace, security and harmony. ${ }^{83}$

He also advocated these concepts in the forum held in Georgetown University: "Islam and the West could and should live and co-exist together in peace and harmony, as the common denominators that link them outweigh their differences. There are many facts which facilitate this reconciliation between Islam and the West". ${ }^{84}$

As with the activity of the BMENA, Turkey emphasized women's role in its development. Turkey was the host country of the first ministerial conference on women's roles in the development of OIC member states, held on 20-21 November 2006. İhsanoğlu, Erdoğan and then-Turkish State Minister Nimet Çubukçu attended the conference, and four programs were discussed. These were national policies for empowerment of and eradication of the poverty of women, increasing opportunities for women to participate in both local and national politics, enhancing

83 "Statement by Secretary General at The United Nations General Assembly's High Level Dialogue On Inter-Religious and Inter-Cultural Cooperation for Peace", 5 October 2007, <http://wnw.oicoci.org/topic_detail.asp?t_id=1324\&x_key=>, (access date 15 February 2011).

84 "Preface", < לttp:// www. oic-oci.org/english/article/Preface\%20ibsanoglu.pdf>, (access date 15 February 2011). 
participation and access to education, and stopping domestic violence against women. ${ }^{85}$

\section{Conclusion}

This paper examined Turkey's roles of norm entrepreneur and norm transmitter toward the Middle East from constructivism perspectives. At first part, this study overviewed previous studies about norm and norm spread. Concerning norm diffusion, constructivists, especially Florini, Finnemore and Sikkink, and Acharya contribute to make framework for study. They try to show or establish norm spread routes and directions. Florini applies evolutional theory to norm spread and showed two ways of norm spread. Yet, she only focuses on strong international norm and does not consider socialization process enough. The distinguished contribution to norm study by Finnmore and Sikkink is showing clear route about norm diffusion process. They also emphasize socialization process. Yet, like Florini they also deal with only international norms and their transformation. Unlike them, Achayra's major concern is how international norms transform to fit with inherent norms in each region. Acharya's trial is useful for analysis to norm of non-Western world. Florini and Finnemore and Sikkink take notice on the role of norm entrepreneur. On the other hand, Acharya focuses on the role of norm transmitter.

In second part, this paper presented framework of Turkey's norm entrepreneur and norm transmitter roles, and applied it to specific examples. As the examples of norm entrepreneur, Ankara Forum and Turkish model were taken in this paper. On the other hand, Turkey's activities in DAD and OIC were examples of norm transmitter.

85 "Report of the First Ministerial Conference on Women's Role in the Development of OIC Member States", 20-21 November 2006, < http:// www. oic-oci.org/english/conf/ women/1st/OIC-REP-WOM-CONFFINAL-06.pdf>, (access date 5 May 2011). 
As norm entrepreneur, Turkish government and TOBB planned to export domestic industrial project to Palestine through Ankara forum. Turkey's industrial project was favorably received by People in Palestine and Israel, however, volatile situation in both countries blocked Turkey's trial. Meanwhile, Turkish model is broadly accepting in some Middle Eastern countries, especially Egypt and Tunisia after the Arab Spring. The feature of Turkish model is non-aggressiveness. JDP's domestic and economic policies are referred as ideal types from other countries.

Concerning Turkey's norm transmitter role, this paper constructed three steps (norm emergence $\rightarrow$ norm diffusion and localization (Turkonized norm) $\rightarrow$ norm diffusion). JDP is a norm transmitter which worked norm entrepreneur not only in domestic norm diffusion but also in regional organizations. According to Acharya, norm localization has four dimensions of localization: prelocalization, local initiative, adaptation, and amplification and universalization. In Turkey's case, prelocalization is the period from the birth of Republic of Turkey to Helsinki conference on December 1999. The predecessor of JDP, Welfare Party and Virtue Party's experience is important as prelocalization process. Pro-Islamic party slowly adapted and compromised to European norms. The local initiative has been led by JDP. JDP started from young members from Virtue Party and totally threw the influence of Necemettin Erbakan away. The main members of JDP keenly realized Erbakan's ideas, and the necessity of adaptation to Western idea to resist Kemalist pressure. The insistence of conservative democracy is the phase of adaptation. Conservative democracy is one of the localized ideas which fused democracy with Turkish conservatism and Islamic traditions. Gradually, Turkey's domestic adaptation spreads to other countries. This is the phase of amplification and universalization. Turkey began to the role of norm transmitter to the Middle East region through regional institutions like BMENA and OIC. Yet, Turkey did not success in the phase between prelocalization and local initiative through DAD project in BMENA. It is because almost all Middle 
Eastern countries knew that this organization was led by US, and opposed the American way of transformation. In the case of OIC, Turkey continues to make effort to be local initiative.

Turkey's trials of norm entrepreneur and norm transmitter to Middle East region are not always success. Ankara Forum and DAD project did not work well as Turkey wanted. There are some obstructive factors. These are negative image of U.S. Iraqi policies, volatile situation in Palestine and Israel, and authoritarian regimes. In 2011, the discourse of Turkish model was popular in Middle Eastern countries. To keep this image against Middle Eastern people, Turkey should pursuit to sound economic policies and pro-people's stance against authoritarian regimes. It is for this reason that responses toward Syria will be a touchstone case for Turkey's norm entrepreneur and norm transmitter role. 